\author{
(online) $=$ ISSN $2285-3642$ \\ ISSN-L = $2285-3642$ \\ Journal of Economic Development, Environment and People \\ Volume 6, Issue 4, 2017 \\ URL: http://jedep.spiruharet.ro \\ e-mail: office jedep@spiruharet.ro
}

\title{
The Effect of Government Spending on Education in Aceh Province Indonesia
}

\author{
Sartiyah ${ }^{1}$, Sri Hartoyo ${ }^{2}$, Yusman Syaukat ${ }^{2}$ and Rina Oktaviani ${ }^{2}$ 国 \\ ${ }^{1}$ Faculty of Economics and Business, Syiah Kuala University Banda Aceh Indonesia \\ ${ }^{1}$ E-mail: sartysabang@unsyiah.ac.id \\ ${ }^{2}$ Department of Economics, Faculty of Economics and Management Bogor Agricultural University, Indonesia \\ 2 Email: shty@indo.net.id; ysyaukat@gmail.com; r_oktavi@yahoo.com
}

\begin{abstract}
This study was conducted to examine the effect of government spending on education, poverty, income per capita and the dummy of the main and newly established regions to education in Aceh Province. The data used in this study are panel data of 23 city districts in Aceh Province from 2008 to 2013. To estimate multiple models of data panels, Common Effect Model and The SYSLIN Procedure 2 SLS Estimation using SAS 9.31 Program are used. The study showed that government spending on education, income per capita in main regions are positively and significantly effect on education, while poverty negatively affects on education in Aceh Province. However, education has a small response to government spending on education in Aceh Province. According to the results of the research, it is recommended for local governments to intensify the service and supervision of education in the newly established regions, specifically in remote areas.
\end{abstract}

Keywords: Aceh Province Indonesia, Education, Government spending, Poverty.

JEL Codes: $H 4,125$, and 126

\section{Introduction}

\subsection{Background}

Aceh Province has experienced a dark history in development for three decades since 1980, due to various problems in development such as security conflicts and The Military Operations Area (DOM) from the 1980 s to the 2000s, as well as the catastrophic earthquake and tsunami disaster of 2004. The prolonged problems have caused the development in Aceh Province experiencing obstacles and backwardness, both in the economic and non-economic sectors. Educational development is one of the sectors that have been impacted by the problems.

The education level measured by the years of schooling (YoS) is one of the determinants of Human Development Index (HDI). Years of schooling in Aceh Province from 2010 to 2015 increased by only 1,082 percent per year, from 8.28 years to 8.77 years. The increase indicates that the average length of education for the people of Aceh Province during the year was very slow. This is directly suspected to affect the development of Human Development Index in Aceh Province which also experienced lag from other provinces. Human Development Index in Aceh Province in 2010 amounted to 67.09 increased to 69.45 in

Corresponding author. Tel.: (+ 628116891066);

E-mail address: (sartysabang@unsyiah.ac.id). 


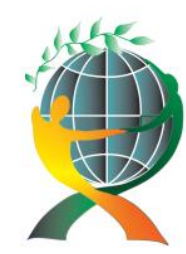

\author{
(online) $=$ ISSN $2285-3642$ \\ ISSN-L = $2285-3642$ \\ Journal of Economic Development, Environment and People \\ Volume 6, Issue 4, 2017 \\ URL: http://jedep.spiruharet.ro \\ e-mail: office jedep@spiruharet.ro
}

2015 or increased by 0.703 percent per year. The increase in educational level and the Human Development Index was very low, whereas the average government spending on education at that period was 7.65 percent annually per year.

Improving the quality of education is a major part of the development strategy, and is controversial as the increase allows a country to improve the economy. Schultz (1961) found that human capital investment, especially in education, has an impact on the increase in income per worker. Further recognizing that human capital has a very important role in economic growth. Further investment of human capital according to Hanushek (2005) of his study stating that the role of quality education promotes economic welfare, specifically states that there is a strong relationship between the ability of the population with individual income, income distribution, and economic growth.

The development of YoS and HDI as described above seemed to be very slow and had been a dilemma. While sub-national spending in the education sector large enough, only a small increase in HDI was occurred. This phenomenon is expected to impact on the slow development of regions in producing output in Aceh province. The importance of human capital advancement is explained by Card (1999) that low level of education will result in low outcomes, whereas higher education will result in high outcomes. Supporting the Card, Hanushek, and Woessmann (2008), in their study of the countries included in the Organization for Economic Co-operation and Development (OECD) stated that the duration of education or RLS has a significant role to the growth of a country's output. This could lead to the conclusion that the accumulation of education plays a very important role in the labour market, greater employment opportunities, and better jobs compared to the lower educated population.

Amartya Sen (2006) explained the importance of educational development, and mentioned countries with high-income levels had high educational standards and vice versa with low education affected lowincome people. Yahya (2012) supporting the idea by conducting a study using granger causality in Malaysia stated that human capital education played a very important role in influencing economic growth in Malaysia. This statement emphasizes the importance of education to regional economic development. Aulia (2011) in his study also found that government spending in education is an investment of human capital that increases labour productivity and technology as a proxy of educational investment, and will eventually increase economic growth in real terms. Either in short-term or long-term, it will affect each other's economic growth and GDP.

Efforts have made by the Aceh Provincial Government to increase the level of community education through education expenditures. However, it is also inseparable from other factors namely the existence of the number of poor people, the number of school-age residents served by the education expenditures. In other words, poverty and the age of the population are expected to have a role in improving education.

The implementation of Law No. 22 and No. 25 on Regional Autonomy Year 1999 had caused euphoria in the expansion of the region in Aceh Province. The law had increased the interest of Aceh region to expand the region and had resulted in 13 municipal districts from 1999 to 2007. This has raised a question on the management and educational service of government spending in the area. Therefore, it is necessary to study 


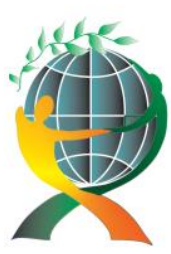

\author{
(online) $=$ ISSN $2285-3642$ \\ ISSN-L = 2285 - 3642 \\ Journal of Economic Development, Environment and People \\ Volume 6, Issue 4, 2017 \\ URL: http://jedep.spiruharet.ro \\ e-mail: office jedep@spiruharet.ro
}

the condition of various factors in influencing education in Aceh Province. Contributions to the journal are welcome from throughout the world.

\title{
1.2 Research Objectives
}

The purpose of this research is to analyze:

1. The growth of educations and government spending on education, poverty, and per capita income in the main regions and the newly established regions in the province of Aceh.

2. Educational responses to government spending on education and other factors in the main regions and the newly established regions of Aceh Province.

\section{RESEARCH METHODS}

\subsection{Location and Research Data}

This research was conducted in the district of the city in Aceh Province. The object of the research was 23 districts of the city in Aceh Province with 13 regions as the newly established region and ten main regions. Of 23 districts, four regions were the mining area, and the remaining 19 regions were the agricultural areas.

The study used panel data consisted of cross-section data for the selection of study sites and time series data from 2004 to 2014. The secondary data used were from the Central Bureau of Statistics. The data used were education, government spending in the education, the number of poor people, per capita income, and dummy dummy of regional expansion. The panel data technique used is adopted from Aghion, Meghir, and Vandenbussche (2006). They used data from several countries to explain the relationship between human capital, other variables and economic performance in the country.

\subsection{Data Analysis Method}

The method of data panel analysis in this study used the Common Effect Model. To analyze the relationships between education with government spending in the education, the number of poor people, and dummy of regional expansion. Multiple Linear Regression Model with panel data referring to Juanda and Junaidi (2012) was used as follows:

Education:

$$
E D U=\beta_{0 i}+\beta_{1} \text { GOVSPEND }_{i t}+\beta_{2} P C A P_{i t}+\beta_{3} P O V_{i t}+\beta_{4} D E R_{i t}+\mu_{i t}
$$

Boi : intercept

$B i$ : slope or coefficient of variables (GOVSPEND, PCAP, POV, and DER)

$\mu$ it : error term

$i \quad: 1,2, \ldots, 23$ (23 the districts of Aceh Province)

$t \quad: 1,2, \ldots, 6$ (number of years, ie from $2008-2013$ ).

Where EDU is the length of schooling (years); is the intercept; GOVSPEND is government spending on education (million rupiah), POV is the poor people (thousand people); PCAP is income per capita (thousand rupiahs), $D E R$ is Dummy Expansion Region, $D=1$ for Main Region and $D=0$ is the newly established region. 


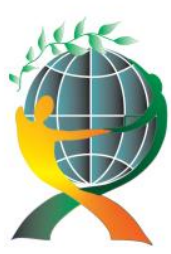

\author{
(online) $=$ ISSN $2285-3642$ \\ ISSN-L = $2285-3642$ \\ Journal of Economic Development, Environment and People \\ Volume 6, Issue 4, 2017 \\ URL: http://jedep.spiruharet.ro \\ e-mail: office jedep@spiruharet.ro
}

$61,62,63$, and 64 are the coefficient parameter for variable GOVSPEND, POV, PCAP, and DER and $\mu$ are error term. The expected values for the coefficients are: $60 i, 61,62,64,>0$ dan $63<0$. Please acknowledge collaborators or anyone who has helped with the paper at the end of the text.

\title{
3. RESULT AND DISCUSSION
}

\subsection{Results of Research}

Development of Education, Government spending on Education, per capita income, Poverty, in Aceh Province. Indonesia's regional expansion began with the enactment of Law No. 22 of 1999; followed by Law no. 32 of 2004 . The regional extension is eagerly awaited by local governments since it will provide opportunities for the region to aspire the wishes of the community in regional development. The Act provides opportunities for regions in Indonesia to conduct regional expansion (Pratikno 2008). In the province of Aceh, the regional divisions were started from October 1999 to January 2007. Initially, there were ten regions in Aceh, and later it is well known as the main regions. The expansion had resulted in another 13 regions, and Aceh now has 23 regencies and municipalities. Detailed expansion of the regions in Aceh Province could be seen in the Table 1.

The first established region was Simeulue District that came from West Aceh District in October 1999. The last one is Subulussalam District which was established in January 2007 and expanded from South Aceh Regency. Until recently, there was no new regional expansion has been done in Aceh Province. The regional expansion of the area illustrates the varied performance of regional development either in the newly established region or in the main regions.

Table 1. Expansion of Regions from the Main Regions in Aceh Province.

\begin{tabular}{cll}
\hline No & The Main Regions & The Newly Established Regions \\
\hline 1 & Banda Aceh City & Simeulue District \\
2 & Sabang City & Singkil District \\
3 & Aceh Besar District & Bireuen District \\
4 & Pidie District & Lhokseumawe City \\
5 & Aceh Utara District & Langsa City \\
6 & Aceh Tengah District & Aceh Barat Daya District \\
7 & Aceh Barat District & Nagan Raya District \\
8 & Aceh Selatan District & Aceh Jaya District \\
9 & Aceh Timur District & Gayo Luwes District \\
10 & Aceh Tenggara District & Aceh Tamiang District \\
11 & - & Bener Meriah District \\
12 & - & Pidie Jaya District \\
13 & - & Subulussalam City \\
\hline
\end{tabular}

Source: http://www.acehprov.go.id/kota.html 


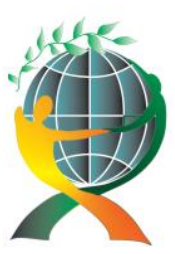

\author{
(online) $=$ ISSN $2285-3642$ \\ ISSN-L = $2285-3642$ \\ Journal of Economic Development, Environment and People \\ Volume 6, Issue 4, 2017 \\ URL: http://jedep.spiruharet.ro \\ e-mail: office jedep@spiruharet.ro
}

\title{
Development Performance of Education, Government spending in Education, Per capita income, and Poor People after Regional Expansion Policy in Aceh Province
}

The regional expansion in Aceh Province had been ended in 2007. Hence, development activities analyzed in Aceh Province were started in 2008. Years of schooling in Aceh Province is still low with an average of about 9 years. The 9 -year education is a junior high school. Education in the Main region is higher than in the newly established region. The years of schooling in Aceh Province in 2009 -2016, is shown in Table 2 .

Table 2. Years of Schooling in Main Region and Newly Established Region Aceh Province in 2009 -2016 (year)

\begin{tabular}{ccc}
\hline Year & Main Region & The Newly Established Region \\
\hline 2010 & 8.6 & 7.69 \\
2011 & 8.68 & 7.89 \\
2012 & 8.77 & 8.09 \\
2013 & 8.84 & 8.21 \\
2014 & 8.99 & 8.35 \\
2015 & 9.21 & 8.47 \\
2016 & 9.32 & 8.55
\end{tabular}

Source: Central Bureau of Statistics Aceh Province (2017)

Government spending on Education in the main-regions and newly established-regions of Aceh Province from 2008 to 2016 had a positive trend, but the government spending in education was greater in the mainregions than that in the newly established-regions. Government expenditures in education between in the main-regions and in the newly established-regions could be seen in Figure 1.

Figure 1 showed that on average, government spending on education in the main-regions and the newly established-regions increased from 2008 to 2016, but it was greater in the main regions compared to the newly established-regions. Growth in education expenditures in the main-regions from 2008 to 2014 was about 17.4 percent per year, while in the new established-regions was around 18.5 percent per year. The positive trend of government expenditures in education sector could indicate the effort of the regional government to develop human capital. 


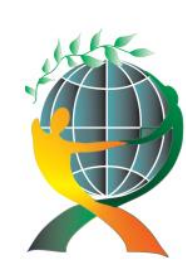

\author{
(online) $=$ ISSN $2285-3642$ \\ ISSN-L = $2285-3642$ \\ Journal of Economic Development, Environment and People \\ Volume 6, Issue 4, 2017
}

URL: http://jedep.spiruharet.ro

e-mail: office jedep@spiruharet.ro

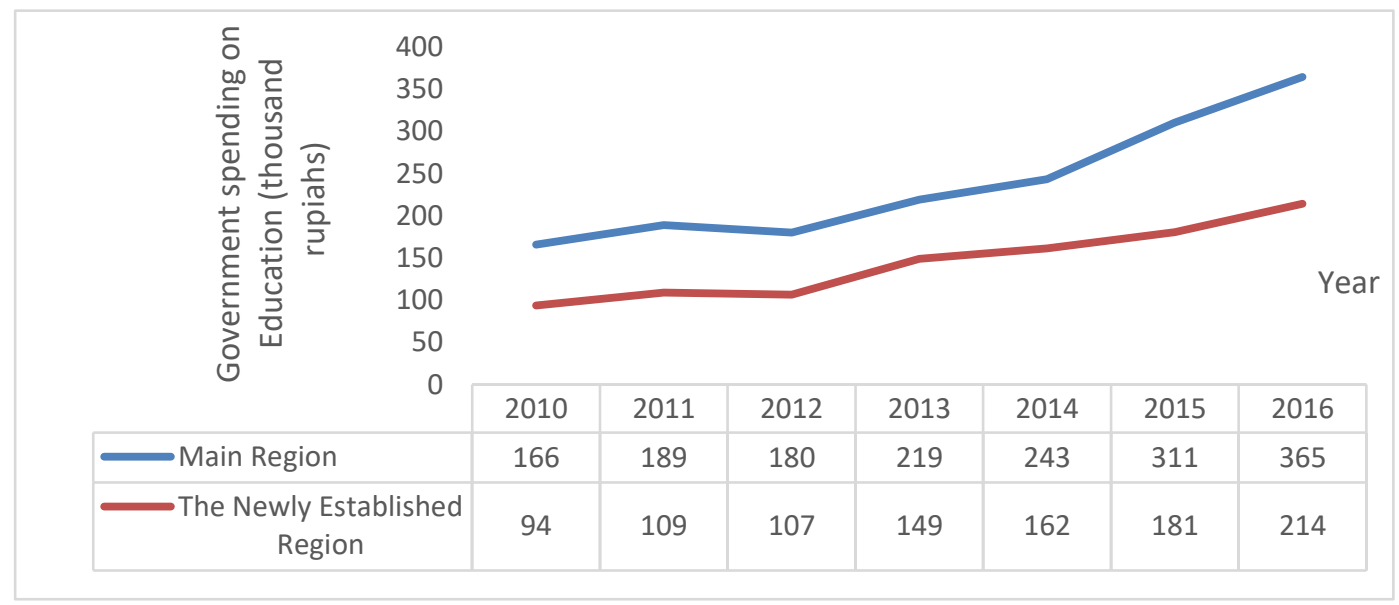

Fig. 1 : Government Expenditures on Education in the Main and Newly Established Regions of Aceh Province.

Per capita income also plays a role in supporting the community in obtaining educational facilities. Figure 2 demonstrated wide differences in per capita income in Aceh Province from 2008 to 2014 between the main-regions and the newly established-regions. Per capita income in main regions is much greater than that in the newly established-regions. Per capita income of all districts of Aceh province was varied from 6 to 8 million IDR per year, except for Banda Aceh as the capital city of the province which had its per capita income around 13 million IDR per year. The growth of per capita income in the main regions was increased 1.07 percent and in the newly established-regions was 0.397 percent per year. Per capita income previously described could illustrate the ability of the community to obtain education services which were still low and very limited.

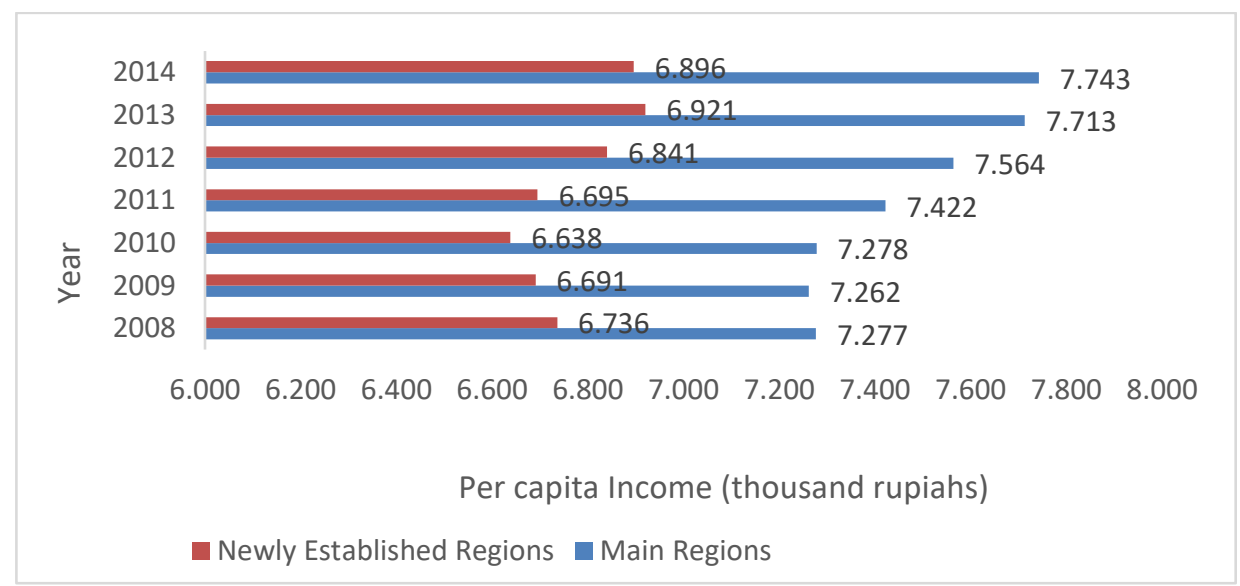

Fig. 2: The Average per capita income of Main and Newly Established-Regions in Aceh Province in 2008-2014 


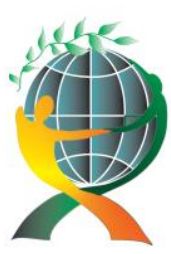

\author{
(online) $=$ ISSN $2285-3642$ \\ ISSN-L = $2285-3642$ \\ Journal of Economic Development, Environment and People \\ Volume 6, Issue 4, 2017 \\ URL: http://jedep.spiruharet.ro \\ e-mail: office jedep@spiruharet.ro
}

Another factor that affects educational attainment in the province of Aceh is the number of poor people. Poverty reflects the limitations in purchasing power, including getting an education due to low income. Conversely, the smaller the number of poor people, the greater the opportunity to get education services because of its greater ability to pay the cost of education. Therefore, it is assumed that an increase in the number of poor people will decrease the average level of education, and vice versa. The growth of the number of poor people could be seen in Figure 3 .

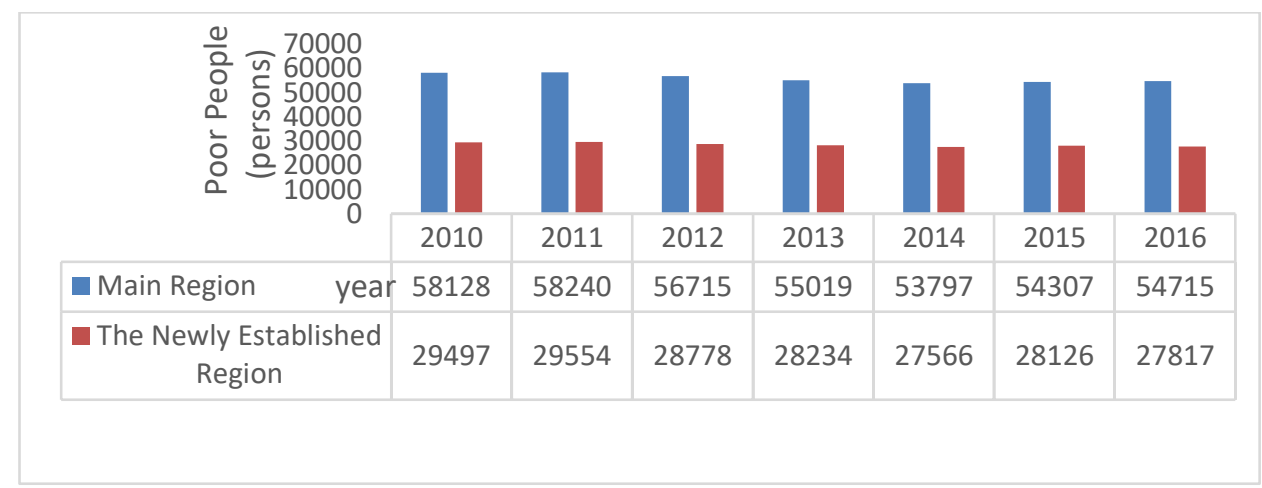

Fig. 3: Growth of the Poor People in Aceh Province 2008-2016

The number of poor people in the main-regions was greater than that in the newly established-regions, and it had a declining trend. The number of poor people in the main areas decreased by 2.5 percent per year, while in the newly established regions, the number of poor people decreased by 1.8 percent per year.

\title{
3.2 Discussion
}

\section{Influence of Government Spending on Education, Poor Population, Per Capita Income to Education in Aceh Province}

The estimation result of multiple linear equations shows that education significantly influenced by government expenditure in the education sector (GOVSPEND $\left.{ }_{i t}\right)$, the number of poor people ( $\left.P O V_{i t}\right)$, per capita income (PCAP $i t)$, and the dummy expansion regions (DER it ). All of these factors affect education by 0.4818 percent. This means that government expenditure in education, poverty, per capita income and the dummy of regions affect education by 48.18 percent, and the remaining 52.82 percent influenced by unobserved factors. Education is influenced by government spending on education, per capita income, and the number of poor $F$ test results show Probability $>F=<0.0001$. The $F$ test result indicates the significant influence of Government spending on Education, per capita income, and the poor population to the education of Aceh Province. The factors affecting on education could be seen in Table 2. 


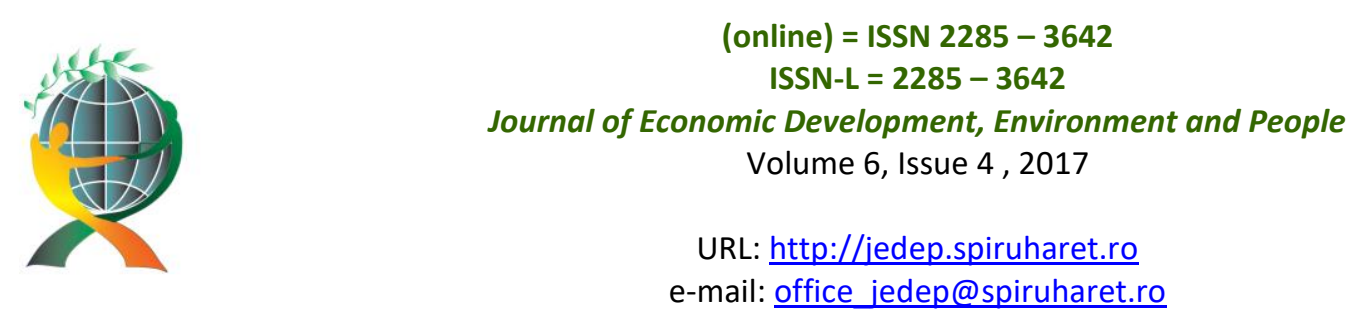

Table 2. Estimation Results of Equations Model of Education.

\begin{tabular}{|c|c|c|c|}
\hline Variable Eksogen & $\begin{array}{l}\text { Parameter } \\
\text { estimation }\end{array}$ & Elasticity & Prob $>|t|$ \\
\hline Intercept & 7.95754 & - & $<0.0001$ \\
\hline $\begin{array}{l}\text { Government Spending on Education } \\
\left(\text { GOVSPENDi } i_{i t}\right)\end{array}$ & 0.00667 & 0.101479 & 0.0001 \\
\hline Income Per capita (PCAPit) & 0.12275 & 0.074162 & $<0.0001$ \\
\hline Poverty $\left(P O V_{i t}\right)$ & -0.01895 & -0.080119 & $<0.0001$ \\
\hline Dummy Expansion Region (DER ${ }_{i t}$ ) & 0.60007 & - & 0.0003 \\
\hline
\end{tabular}

\section{Government Spending on Education}

Government Spending on Education is an important factor for providing public education infrastructure or facilities. It is expected to contribute positively to improving education in the regions. The estimated coefficient of government spending on education is 0.00667 . This implies that the Government Spending on Education has a lower impact to the educational level in the regions. In other words, if there is a change in government spending on education amounted to 1 million IDR, it will just increase education for 0.00667 years. The results are supported by Al-Mukit (2012) who found that there was a positive correlation between government spending in education with education in Bangladesh.

Furthermore, the elasticity of government spending on education amounted to 0.101479 . The elasticity indicates that for every increase in government spending around 10 percent, the educational level will increase only 1.01479 percent. This suggests that the educational level in the short-term is inelastic to government spending on education. Mladen (2013) explains that human capital is the most important asset for the company and suggests that human capital investment should be a priority so that the benefits for the economy, communication and collaboration between markets and schools will be closer. Mladen suggested improving the curriculum at the university linked to labor market requirements.

\section{Income per capita}

Income per capita has a positive and significant influenced on education in Aceh Province with 99 percent confidence level. The estimation results show that a 10 thousand rupiahs increased in income per capita will increase the education in Aceh Province by 0.12275 years. The relationship between income per capita and education is inelastic by 0.074162 . This means that if the income per capita increases with one percent that will change the education in Aceh Province around 0.074162. The idea is supported by Ferguson (2007) in his study about the relationship of family income to education. His study showed that the education 


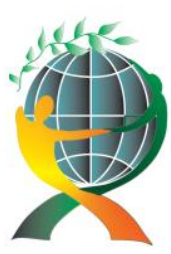

\author{
(online) $=$ ISSN $2285-3642$ \\ ISSN-L = $2285-3642$ \\ Journal of Economic Development, Environment and People \\ Volume 6 , Issue 4 , 2017 \\ URL: http://jedep.spiruharet.ro \\ e-mail: office jedep@spiruharet.ro
}

of children from low-income families was behind their peers who came from higher-income families. The incidence, depth, duration and the timing of poverty are all affecting the level of educational attainment.

\title{
Poverty
}

Poverty is closely related to the ability to gain an education. Children from the poor family usually do not have a higher level of education because the family cannot pay the cost of education. Furthermore, the children sometimes have to participate in earning a living for the family and do not have time to study. Therefore, poverty also related to time available for studying. Those conditions imply the negative relationships between poverty and education.

The result of the study supports the idea, that the number of poor people had a negative effect on education around 0.01895 with 99 percent confidence level. This means that the increase of poor people by 10 thousand has caused the education decreased by 0.01895 year and vice versa. The response of the poor to education is small and inelastic by 0.080119 . The Government of Aceh Province gives more opportunities to the poor to gain education services. It is expected the number of poor people will be decreased along with the increase opportunities to education services. However, even though the number of poor people increased significantly, the education will only slightly decrease. This indicates that education is inelastic to poor people.

\section{Dummy Expansion Region}

Dummy areas are important to be studied because it is a necessity to understand the performance of the main regions and the newly established regions in public education. The results of model estimation show that the dummy extension region has positive and significantly influenced the level of education. The main regions have a major role in supporting the improvement of education. The coefficient for dummy areas is 0.60007 with the confidence level of 99 percent. This indicates that the main regions have a greater influence on educational levels than that of the newly established regions. On the other hand, the newly established regions have lag in education development compared to the main regions. Furry (2013) with his study on the performance of the expansion regions had similar finding. Serang district as the expansion region had its performance in public services almost similar to its main region. However, in term of performance and services in education, Serang Regency was still lag behind the main region.

\section{CONCLUSIONS AND RECOMMENDATION}

\subsection{Conclusions}

According to the research results, there are some conclusions that could be drawn as follows:

1. Educational developments, government spending on education, per capita income, and poverty progress slowly in the newly-established regions compared to the main regions.

2. The results of the study indicate that the Government spending on education, per capita income is positively and significantly influenced the education, while the number of poor people negatively affects 


\author{
(online) $=$ ISSN $2285-3642$ \\ ISSN-L = $2285-3642$ \\ Journal of Economic Development, Environment and People \\ Volume 6, Issue 4, 2017 \\ URL: http://jedep.spiruharet.ro \\ e-mail: office jedep@spiruharet.ro
}

the education. The influence of the whole factors to education is greater in the main regions than that in the newly established regions of Aceh Province.

3. The education has a smaller response to changes in government spending on education and the per capita income. The response of education is also lower to the number of poor people. This means it has a positive effect on the regions because there is a slight influence of poverty on the level of education.

\title{
4.2. Recommendations
}

According to the results of the study, it is recommended that the Aceh Provincial Government should intensify its services and supervision in the education sector in the newly established regions, specifically the newly established regions in the remote areas.

\section{References}

[1] Pemerintah Daerah Aceh. http://www.acehprov.go.id/kota.html. 2017.

[2] A. Muktdair. Public Expenditure on Education and Economic Growth: The Case of Bangladesh. International Journal of Applied Research in Business Administration and Economics. 2012. Vol. 01. 04. Article No. 02.

[3] A. Hafidh. Analisis Hubungan Pengeluaran Pendidikan dan Pertumbuhan Ekonomi Dengan Menggunakan Pendekatan Kausalitas Granger. Jurnal Ekonomi \& Pendidikan. 2011. Vol. 8 No. 2, pp.125-141.

[4] Card, David. The Causal Effect of Education On Earnings. Elsevier Science. 1999. Vol 3. Part A, pp 1801-1863 California.

[5] Central Bureau of Statistics Aceh Province. Aceh Dalam Angka. 2015.

[6] F. H. B, Bovaird, S, Mueller, MP. The impact of poverty on educational outcomes for children. Paediatr Child Health. 2007. Vol 12. No. 8: 701-706.

[7] F, Ratry and Hadi, PR Sasana. Evaluasi Dampak Pemekaran Daerah Terhadap Kinerja Pelayanan Publik Di Kota Serang. Diponegoro Journal of Ecoconmics. 2013. Vol 2, No 3. pp. 1-13.

[8] H. Eric A. and Ludger Woessmann. The Role of Cognitive Skills in Economic Development". Journal of Economic Literature. 2008. Vol. 46, No.3, pp. 607-668.

[9] K. Merang et. al. Pengaruh pengeluaran Pemerintah Sektor Pendidikan dan Kesehatan Terhadap Indeks Pembangunan Manusia Di Kabupaten Kutai Timur. Jurnal Ekonomi, Manajemen dan Akuntansi. Volume 18, (2), 2016. ISSN print: 1411-1713.

[10] L. Misty and D. Tissington, Laura. The effects of poverty on academic achievement.Educational Research and Review. 2011. Vol. 6 (7), pp. 522-527.

[11] M, Mehmet and Sezerb, Sevgi. The effect of education expenditure on economic growth: The case of Turkey. Procedia - Social and Behavioral Sciences. 2014. 109. 925 - 930 \& 1877-0428 


\author{
(online) $=$ ISSN $2285-3642$ \\ ISSN-L = $2285-3642$ \\ Journal of Economic Development, Environment and People \\ Volume 6, Issue 4, 2017 \\ URL: http://jedep.spiruharet.ro \\ e-mail: office jedep@spiruharet.ro
}

[12] M, Luise Mladen, Rocsana Tonis (Bucea-Manea). Premises for Adapting Curriculum and Educational Package to Labor Market Requirements. Journal of Economic Development, Environment and People Vol. 5, Issue 2, 2016

[13] U. Aminu. Human Capital: Education and Health in Economic Growth and Development of the Nigerian Economy. British Journal of Economics, Finance and Management Sciences. October 2011, Vol. 2 (1).

[14] Y. Mohd et al. Expenditure and Economic Growth: A Causal Analysis for Malaysia. Journal of Economics and Sustainable Development. 2012. Vol.3, No.7, 2012.

[15] S. Theodore. W.Investment in human capital. American Economic Review. 1961. Vol. 61. pp.1-17. 